\title{
The interaction between land subsidence and urban development in China
}

\author{
Y. Yang ${ }^{1,2}$, R. Wang ${ }^{1}$, Y. Zhou ${ }^{1,2}$, Y. Jiang ${ }^{1}$, and X. Wang ${ }^{1}$ \\ ${ }^{1}$ Beijing Institute of Hydrogeology and Engineering Geology, Beijing, China \\ ${ }^{2}$ School of Earth and Space Sciences, Peking University, Beijing, China \\ Correspondence to: Y. Yang (alovelystair@163.com) \\ Published: 12 November 2015
}

\begin{abstract}
The Yangtze River Delta and North China Plain are experiencing serious land subsidence development and are also the areas that have undergone the fastest urbanization. Rapid urban development inevitably requires more water resources. However, China is a country with small per capita water resources, nonuniform distribution of water resources, and over-exploitation of groundwater - all of which are critical factors contributing to the potential for a land subsidence disaster. In addition, land subsidence has brought about elevation loss, damaged buildings, decreased safety of rail transit projects, lowered land value, and other huge economic losses and potential safety hazards in China. In this paper, Beijing, a typical northern Chinese city deficient in water, is taken as an example to explore (a) the problems of urban development, utilization of water resources, and land subsidence development; (b) the harm and influence of land subsidence hazards on urban construction; and (c) the relationship between urban development and land subsidence. Based on the results, the author has predicted the trend of urban development and land subsidence in Beijing and puts forward her viewpoints and suggestions.
\end{abstract}

\section{Introduction}

Since the 20th century, the issue of land subsidence attracted increasing, global attention in the urban development and construction industries. This attention has continued to the present, and a lot of work has been done in monitoring and studying land subsidence disasters and their prevention (Zhang and Yang, 2010).

The monitoring and study of land subsidence disasters in China began in the 1920 s, and revealed that the distribution and development of subsidence is largely influenced by urban construction (Zhang and Wei, 2005). Beijing, the capital of China, is representative of the Chinese cities that have the fastest rates of land subsidence development in the country. It is also representative of other cities in North China that are deficient in water. From 2007 to the present, the maximum annual settlement rate in the Beijing Plain was more than $100 \mathrm{~mm} \mathrm{a}^{-1}$, and land subsidence may develop rapidly. Therefore, the damage and other impacts inflicted by land subsidence disasters must be seriously considered for urban development in Beijing and elsewhere in China.

\section{Urban development in China}

The formation of urban areas in China has been ongoing for several thousand years; however, China's urbanization was relatively slow until the last decades of the 20th century. The urbanization level in 1949 was only $10.6 \%$ (Zhuang et al., 2012), but accelerated in the 1980s. By the end of 2013, urban residents in China comprised $53.73 \%$ of the total population. It is predicted that in 2050, urban residents will comprise about $75 \%$ of the total population and the urban population may exceed to 1 billion ( $\mathrm{Gu}, 2010)$.

With the rapid development of urbanization and the sharp increase in the urban population, deficiencies in water and land resources have been some of the most important factors influencing the sustainability of the urbanization process. More than 600 cities in China (nearly two-thirds of the country's cities) are deficient in water, and approximately 110 other cities face serious water deficiencies. To satisfy the demand for water for urban development and population increases, the majority of cities have no choice but to mine for groundwater. Land resources are also a concern. Given eleva- 


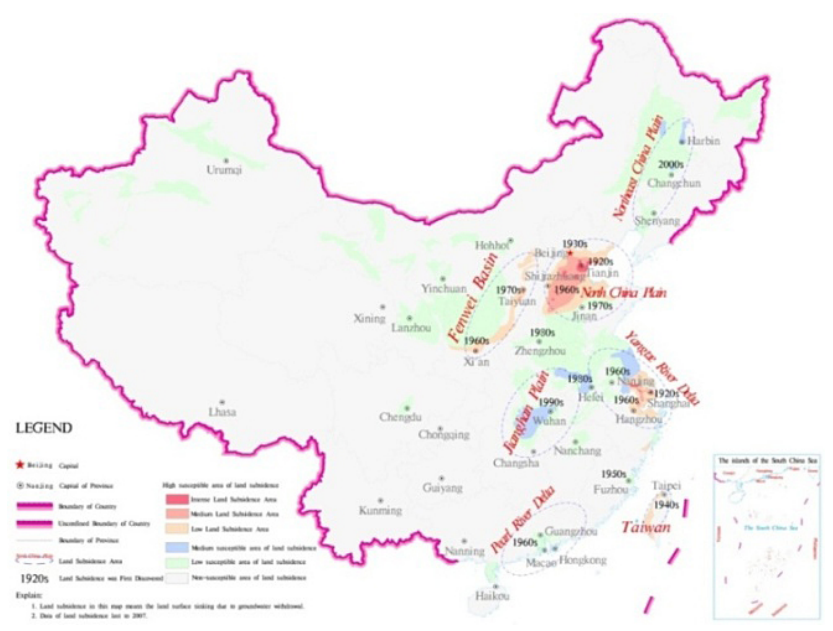

Figure 1. Main regions of land subsidence in China, with years subsidence was discovered.

tion, temperature, rainfall, and geological and other factors, the area of land suitable for modern habitation is less than $50 \%$ of China's total area. An even smaller percentage of the land is suitable for urban development and construction. Therefore, the loss of land resources caused by land subsidence has received much attention.

\section{Land subsidence development in China}

The Yangtze River Delta and North China Plain experienced China's earliest urban development and fastest urbanization. They are also the regions with the most obvious land subsidence. By the 1930s, Shanghai was already the largest financial center in the Far East (Wang, 2014), with large building density and early mining of groundwater. It was the first area in China to show land subsidence. Tianjin and Beijing in the North China Plain and other provinces and cities in the Yangtze River Delta and Fen-wei Basin, successively experienced land subsidence (see Fig. 1).

\section{Impact of urban development on land subsidence}

\subsection{Analysis of urban development and water resources}

Beijing is a city with a long history. Since 1949, Beijing has operated under six different urban plans and has grown continuously. The current vision of the city as a national political and cultural city follows the city's early development as an industrial base and then a center of science and technology. Beijing's urban planning has been constantly updated to reflect these changes. For example, its current "two axle - two belts - multicenter" spatial layout (shown in Fig. 2) is significantly different from the early single-center layout.

Beijing is also extremely deficient in water resources, as noted previously. In 2014, the water resource per capita

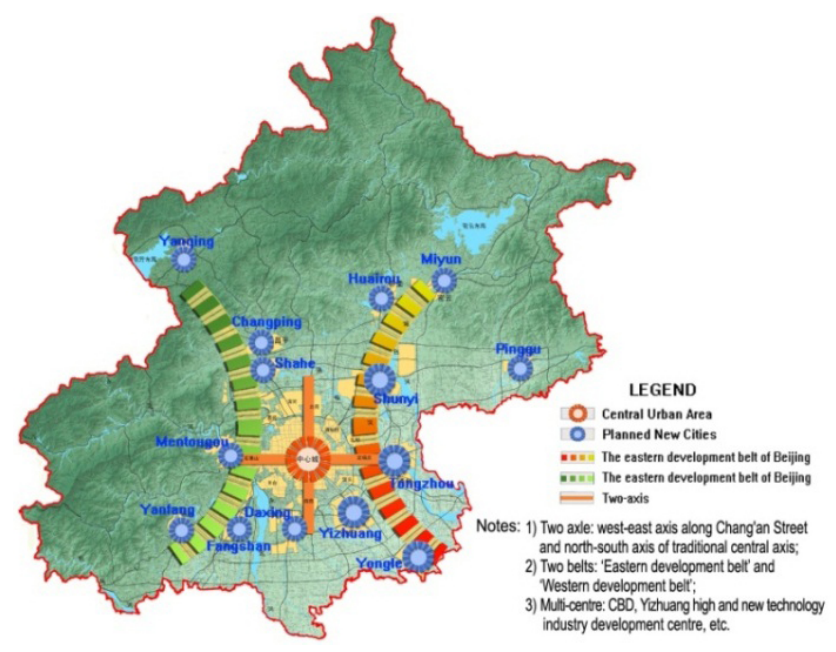

Figure 2. Beijing's planned spatial structure (2004-2020).

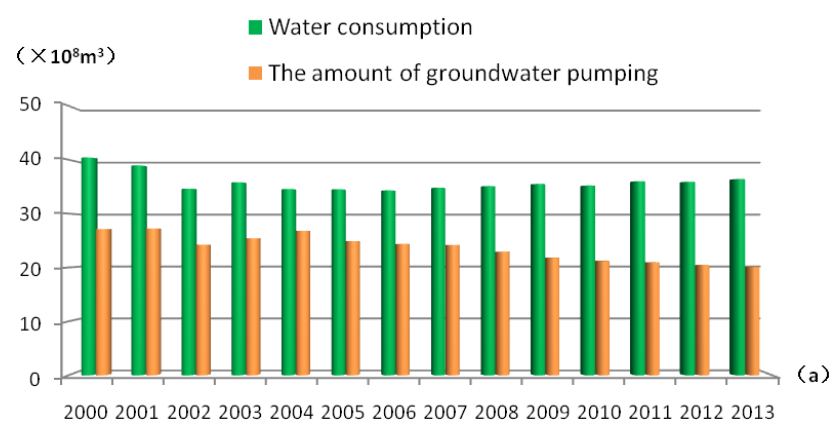

Figure 3. Water consumption and amount of groundwater pumping in Beijing (2000-2013).

in Beijing was only $154.8 \mathrm{~m}^{3}$ per person, approximately $1 / 14$ of the national per capita level and 1/44 of the global per capita level (Cao, 2014). Groundwater consumption accounts for approximately two-thirds of the total urban water consumption (shown in Fig. 3).

To relieve the water resource burden caused by urban development and reduce groundwater pumping, Beijing $\mathrm{Mu}-$ nicipal has strengthened its water resource management, actively introduced external water resources (such as the Southto-North Water Diversion Project), enhanced the utilization of reclaimed water, optimized the water consumption structure, and taken other measures that have yielded remarkable results (see Fig. 4).

\subsection{Analysis of urban development and land subsidence}

The factors influencing land subsidence development in Beijing mainly include (1) active fault and structure development and geologic features and a thicker quaternary system of a compressible clay layer; and (2) over-exploitation of groundwater. The latter is the primary cause of fast development of land subsidence. Figure 5 shows the relationship be- 
Table 1. Urban development and land subsidence development in Beijing.

\begin{tabular}{|c|c|c|}
\hline Year & Urban development & Land subsidence development condition \\
\hline $\begin{array}{l}\text { Before } \\
1930 \mathrm{~s}\end{array}$ & $\begin{array}{l}\text { The urban area was }<100 \mathrm{~km}^{2} \text { and the scale of } \\
\text { modern industry was very small. }\end{array}$ & Land subsidence was not discovered. \\
\hline $\begin{array}{l}1930 s- \\
1940 s\end{array}$ & $\begin{array}{l}\text { Beijing's downtown began to expand, and } \\
\text { exploitation of groundwater began on a small } \\
\text { scale. }\end{array}$ & $\begin{array}{l}\text { Slow development of Xidan-Dongdan belt } \\
\text { began. }\end{array}$ \\
\hline $1950 \mathrm{~s}$ & $\begin{array}{l}\text { Heavy industry began, groundwater mining } \\
\text { increased, and the city area was expanded to } \\
\text { the third ring road. }\end{array}$ & $\begin{array}{l}\text { In East Bali Village and Jiuxianqiao, the local } \\
\text { settlement rate was less than } 5 \mathrm{~mm} \mathrm{a}^{-1} \text {. }\end{array}$ \\
\hline $\begin{array}{l}1960 \mathrm{~s} \\
1970 \mathrm{~s}\end{array}$ & $\begin{array}{l}\text { Steel, machinery, and other heavy industry } \\
\text { rose rapidly, and Beijing became one of the } \\
\text { most important industrial bases in China. A } \\
\text { groundwater depression cone formed. }\end{array}$ & $\begin{array}{l}\text { Local subsidence was seen at East Balizhuang, } \\
\text { Dajiaoting, and other areas. The subsidence area } \\
\text { was larger than } 400 \mathrm{~km}^{2} \text {. The maximum } \\
\text { settlement rate reached } 28.2 \mathrm{~mm} \mathrm{a}^{-1} \text {. }\end{array}$ \\
\hline $1980 \mathrm{~s}$ & $\begin{array}{l}\text { The city adjusted its industrial structure and } \\
\text { light industry dominated. Shunyi, Changping, } \\
\text { and other suburban counties developed, and } \\
\text { the urban area expanded to the fourth ring } \\
\text { road. Exploited groundwater accounted for } \\
50 \% \text { of the city's water supply. }\end{array}$ & $\begin{array}{l}\text { Shunyi, Changping, and several other districts } \\
\text { and counties discovered land subsidence, and } \\
\text { the subsidence area was larger than } 2800 \mathrm{~km}^{2} \text {. } \\
\text { The maximum sedimentation rate was } \\
34.5 \mathrm{~mm} \mathrm{a}^{-1} \text {, and the maximum accumulative } \\
\text { settlement was } 722 \mathrm{~mm} \text {. }\end{array}$ \\
\hline $2000 \mathrm{~s}$ & $\begin{array}{l}\text { The new town and satellite town were } \\
\text { developed and were dominated by the third } \\
\text { industry. Large numbers of rail transit projects } \\
\text { and other large projects were constructed. } \\
\text { Groundwater was continuously over-exploited } \\
\text { and accounted for } 70 \% \text { of total water } \\
\text { consumption. }\end{array}$ & $\begin{array}{l}\text { Approximately } 10 \text { districts and counties } \\
\text { discovered land subsidence, and the subsidence } \\
\text { area took up approximately two-thirds of the } \\
\text { total Beijing Plain, approximately } 4300 \mathrm{~km}^{2} \text {. } \\
\text { The maximum settlement rate was greater than } \\
150 \mathrm{~mm} \mathrm{a}^{-1} \text {, and the maximum accumulative } \\
\text { settlement was greater than } 1.6 \mathrm{~m} \text {. }\end{array}$ \\
\hline
\end{tabular}

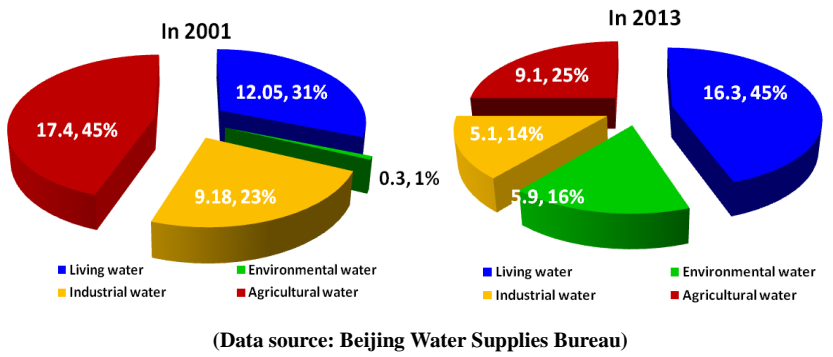

Figure 4. Contrast analysis diagram of water consumption structure in 2001 and 2013 in Beijing.

tween groundwater and land subsidence, as revealed through dynamic monitoring of groundwater and land subsidence research. The land subsidence disaster development condition caused by over-exploitation of groundwater is shown in Table 1 .



Figure 5. Groundwater and land subsidence levels in Beijing.

\subsection{Predictive analysis of urban development and land subsidence development in Beijing}

The planning of new city zone construction, traffic and infrastructure construction, ecological and environmental protection, and conservation of the historic cultural city are the key components of urban development in Beijing. The carrying capacity of resources and the geological and environ- 
mental safety of the Beijing-Tianjin-Hebei region are also issues that must be considered.

Beijing has a serious deficiency of water resources, a high rate of urban construction and population growth, and a particular regional geological background. Given these factors and the hysteresis of land subsidence development, it is predicted that land subsidence around Beijing will continue to develop at a rapid rate. In 5 to 10 years, the settlement rate of the local settlement area will still be greater than $100 \mathrm{~mm} \mathrm{a}^{-1}$. Therefore, balancing the exploitation and supplementation of groundwater is the key for guaranteeing sustainable urban development and preventing a land subsidence disaster in Beijing.

\subsection{Impact of urban development on land subsidence}

The negative impact of urban development and construction on land subsidence reflects in elevation loss, inwelling, acute storm surges, failure of floodwalls, and other serious consequences (e.g. failure of municipal facilities, roads, bridges, underground utilities, levelling signs, and well casings) (Yang, 2015). Subsidence has caused damage to buildings in Shanghai, Tianjin, and other coastal cities and has decreased the safety of rail transit projects. Moreover, subsidence has triggered and aggravated ground fissures and other urban geological disasters and has decreased comprehensive land use value. China will bear the resulting economic loss, which amounts to thousands of billions of renminbi (Ye et al., 2006).

Although influencing urban construction, land subsidence has also restricted future urban development planning.

\section{Conclusions and suggestions}

1. The ecological and environmental carrying capacity is the key factor restricting China's urban development. Managing the relationships among economic construction, population growth, resource utilization, and ecological and environmental protection is the key for realizing sustainable urban development.
2. Over-exploitation of groundwater is the critical factor influencing the development of land subsidence disasters in Chinese cities, and controlling the mining of groundwater is the most effective approach to prevent land subsidence disasters.

3. Stratum structure unit and groundwater flow-field distribution characteristics should be taken as the standard for control zoning; these are required to comprehensively and rapidly promote the prevention and control of land subsidence disasters in China in order to achieve the aim of serving urban development.

\section{References}

Cao, H.: The crisis of water resources need to be solved in Beijing, China Econ, Times, 8, 6, 2014.

$\mathrm{Gu}, \mathrm{C} .:$ China's urbanization space and its formation mechanism, School of Architecture, Tsinghua University, Beijing, 2010.

Wang, D.: Urban planning history of China, Southeast University Press, Nanjing, 2014.

Yang, Y.: Land Subsidence Disaster Prevention and Cure in BeijingTianjin-Hebei Area, China, Urban Geol., 1, 1-7, 2015.

Ye, X., He, Q., Li, S., et al.: Economic loss assessment of land subsidence in the north China plain, China Ocean University Press, Beijing, 2006.

Zhang, A. and Wei, Z.: Land subsidence, Shanghai Scientific and Technical Publishers, Shanghai, 2005.

Zhang, A. and Yang, T.: Latest progress review of research on international land subsidence, Shanghai Geol., 4, 57-63, 2010.

Zhuang, D., Jiang, D., Xu, X., et al.: China's urban space layout of suitability evaluation, Science Press, Beijing, China, 2012. 